\title{
New data on spiders (Aranei) from Eastern Koryakia, Kamchatka Peninsula
}

\section{Новые данные о пауках (Aranei) восточной Корякии, Камчатка}

\author{
Yuri M. Marusik ${ }^{1,2}$, Mikhail M. Omelko ${ }^{3,4}$, Alexander S. Ryabukhin ${ }^{1}$ \\ Ю.М. Марусик ${ }^{1,2}$, М.М. Омелько,
}

\author{
${ }^{1}$ Institute for Biological Problems of the North, FEB RAS, Magadan 685000, Russia. E-mail:_yurmar@mail.ru \\ ${ }^{2}$ Zoological Museum, University of Turku, FI-20014 Turku, Finland. \\ ${ }^{3}$ Gornotaezhnaya Station FEB RAS, Gornotaezhnoe Vil., Ussuriyski Dist., Primorski krai 692533 Russia. E-mail: omelkom@gmail.com \\ ${ }^{4}$ Far Eastern Federal University, Sukhanova 8, Vladivostok 690950, Russia. E-mail: asryabukhin@mail.ru \\ ${ }^{1}$ Институт биологических проблем Севера ДВО РАН, Магадан 685000 Россия. \\ ${ }^{3}$ Горнотаёжная Станция ДВО РАН, Горнотаёжное, Уссурийский р-н, Приморский край, 692533 Россия. \\ ${ }^{4}$ Дальневосточный Федеральный Униесритет, Суханова 8, Владивосток, 690950 Россия.
}

KEY WORDS. Northeast Asia, Far East Asia, new record, Kamchatka Province.

КЛЮЧЕВЫЕ СЛОВА. Северо-Восток Азии, Дальний Восток, новая находка, Камчатский край.

ABSTRACT. Eighty-four species of spiders and one species of harvestman are reported from Eastern Koryakia. 37 species and one family, Agelenidae, are new to Koryakia. Of these, 25 species and seven genera are new to the entire Kamchatka Peninsula. Seven species are illustrated. A list of all species reported from Koryakia is presented and most interesting finds are discussed.

РЕЗЮМЕ. В восточной Корякии, в окрестностях посёлков Тиличики и Ачайваям отмечено 84 вида пауков и один вид сенокосца. Из них 37 видов и одно семейство (Agelenidae) найдены в Корякии впервые. Среди найденных пауков, 25 видов и 7 родов впервые зарегистрированы на Камчатке. Для 7 видов приводятся диагностические иллюстрации. Приводятся список всех видов, известных в Корякии (148), все интересные находки прокомментированы.

\section{Introduction}

Kamchatka Peninsula with 240 reported spider species [Mikhailov, 2013] is one of the worst studied region of Russia in respect to its spider fauna. Only a small in space island regions such as Novaya Zemlya, the Commander Island, Middle and North Kuril islands have fever species. Until recently, only south part of Kamchatka was more or less studied, while northern part, or Koryakia, was almost uninvestigated. First six species from northwestern Koryakia were reported by Marusik et al. [1992]. This number did not change until 2010, when 83 morphospecies were reported from western Koryakia on the basis of material collected by the third author [Marusik et al., 2010]. Since then, one more paper was published about spiders of the eastern Koryakia, Karaginski Island [Marusik \& Khrulyova, 2011]. Besides these three faunistic papers, few species from Koryakia were considered in some taxonomic publications [Marusik \& Koponen, 2010; Omelko et al., 2010]. Up to now, 117 species of spiders and one species of harvestmen are known to occur in Koryakia [Marusik \& Khrulyova, 2011], but only 105 of them are identified to species level.

Recently, the third author visited two localities in eastern Koryakia and collected there some hundreds specimens of spiders. New material contained over three dozen species and a few genera new for Koryakia and Kamchatka. Goal of this paper is to provide: 1) first data about two local faunas in Eastern Koryakia; 2) to provide comments on new species records for Koryakia and Kamchatka; and, 3) to sum up data about species diversity of spiders in Koryakia.

\section{Material and methods}

All spiders were collected by the third author in Olyutorski District in Eastern Koryakia: environs of Tilichiki Village $\left(60^{\circ} 26^{\prime} \mathrm{N} 166^{\circ} 03^{\prime} \mathrm{E}\right)$ in July 3-26, 2012 , and in environs of Achayvayam Village $\left(61^{\circ} 00^{\prime}\right.$ $11^{\prime \prime} \mathrm{N} 170^{\circ} 30^{\prime} 19^{\prime \prime} \mathrm{E}$ ) in July 6-28, 2013 (Map 1). The material was collected either by sifting litter or hand picking in lowland habitats. Spiders were preserved in $75 \%$ ethanol. Material treated here will be shared between the Zoological Museum of the Moscow State University and the Manchester Museum, University of Manchester, UK. The numbers of examined specimen from the two localities are presented in Table 1 in appropriate columns. For all species new to Kamchatka and Koryakia we provide comments. Specimens 


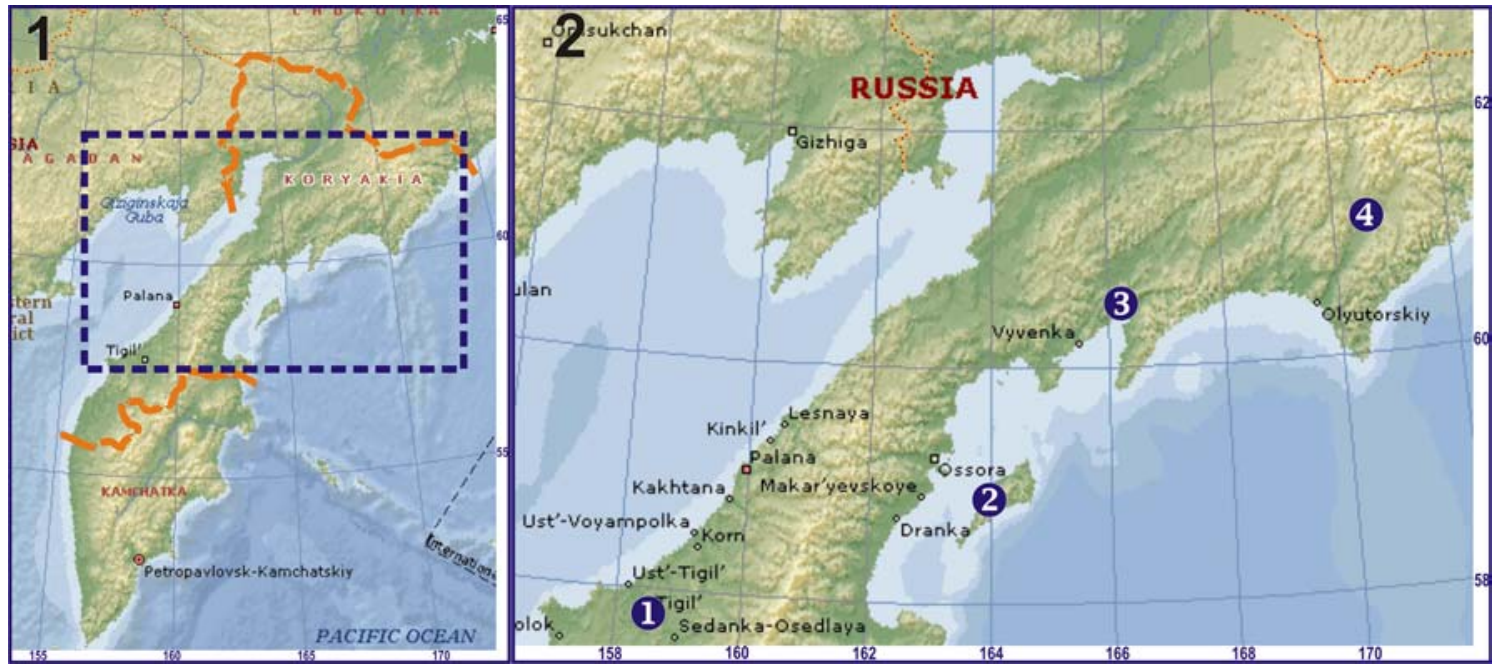

Maps 1-2. 1 - Kamchatka peninsula and boundaries of Koryakia; 2 - collecting localities in Koryakia: 1 - Tigil' [Marusik et al., 2010]; 2 - Karaginski Isl. [Marusik \& Khrulyova, 2011]; 3 - Tilichiki Village; 4 - Achayvayam Village.

Карты 1-2. 1 - п-ов Камчатка и границы Карякии; 2 - точки сборов в Корякии: 1 - Тигиль [Marusik et al., 2010]; 2 - o-в Карагинский [Marusik \& Khrulyova, 2011]; 3 - Тиличики; 4 - Ачайваям.

unidentified to species level are not listed with few exceptions. Seven poorly known species are illustrated. Families, genera and species are listed in alphabetic order. Species marked with asterisk $(*)$ are completely new to Kamchatka, and species marked with ${ }^{\wedge}$ are new to Koryakia. Species for which Koryakia is the easternmost or westernmost locality in the range are marked with ${ }^{\mathrm{E}}$ and ${ }^{\mathrm{W}}$ correspondingly.

Specimens were photographed using an Olympus Camedia E-520 camera attached to an Olympus SZX16 stereomicroscope and the SEM JEOL JSM-5200 scanning microscope at the Zoological Museum, University of Turku. The images taken by the Olympus Camedia were montaged using "CombineZP" image stacking software. Photographs were taken in dishes of different size with paraffin at the bottom. Different sized holes were made in the bottom to keep the specimens in the correct position.

\section{Survey of interesting finds}

\section{AGELENIDAE}

COMMENTS. This family is new to Koryakia. Only one species of the family is known from Kamchatka.

Tegenaria domestica (Clerck, 1758) $\wedge$

COMMENTS. Singleton male was collected inside a building. The species has a Cosmopolitan range [Platnick, 2013], and in most localities is synanthropic.

\section{ARANEIDAE}

Cercidia prominens (Westring, 1851) ${ }^{\wedge}$

COMMENTS. The species distributed across the Holarctic [Platnick, 2013]. Although only one juvenile specimen was collected, we have no doubt about it being identified correctly due to its specific pattern, and because it is the only species of the genus known north of $50^{\circ} \mathrm{N}$.

\section{CLUBIONIDAE}

\section{Clubiona furcata Emerton, 1919*}

Figs 1-5.

COMMENTS. The species is known across the northern Nearctic, and in northeastern Asia [Mikhailov \& Marusik, 1995]. Within Asia it was reported from the Magadan Area only. The species can be easily recognized thanks to "wart" $(W a)$ on the base of embolus (Fig. 3).

\section{DICTYNIDAE}

\section{Arctella lapponica Holm, 1945*}

COMMENTS. The species is known from northern Fennoscandia to northeastern part of Northeastern Territories [Marusik et al., 2000]. Although it is rather common in adjacent Chukotka and Magadan Area, the genus and species were never found in Kamchatka Peninsula before. Although we have on hand only two juveniles it was easy to identify species and genus. Arctella lapponica is a single species of the genus occurring in the North. It lacks any pattern and has a large and more elongate body in comparison to Hackmania prominula (Tullgren, 1948), a northern species lacking pattern.

\section{LINYPHIIDAE}

Agyneta amersaxatilis Saaristo et Koponen, 1998*W

COMMENTS. The species is considered as a senior synonym of A. yakutsaxatilis Marusik \& Koponen, 
Table 1. List of spiders and harvestmen found in Koryakia in four localities: (1) Tigil' Village [after Marusik et al., 2010], (2) Karaginski Island [after Marusik \& Khrulyova, 2011], (3) Tilichiki Village and (4) Achayavayam Village (present data).

Табл. 1. Список видов пауков и сенокосцев найденных в 4 локалитетах: (1) Тигиль [по Marusik et al., 2010], (2) о-в Карагинский [по Marusik \& Khrulyova, 2011], (3) Тиличики и (4) Ачайваям (новые данные).

\begin{tabular}{|c|c|c|c|c|}
\hline & 1 & 2 & 3 & 4 \\
\hline \multicolumn{5}{|l|}{ ARANEI } \\
\hline \multicolumn{5}{|l|}{ Agelenidae } \\
\hline Tegenaria domestica (Clerck, 1758) & & & $10^{x}$ & \\
\hline \multicolumn{5}{|l|}{ Araneidae } \\
\hline Araneus alsine (Walckenaer, 1802) & + & & & \\
\hline Araneus marmoreus Clerck, 1758 & + & & & \\
\hline Araneus nordmanni (Thorell, 1870) & + & & & \\
\hline Araneus yukon Levi, 1971 & + & + & & \\
\hline Araniella proxima (Kulczyński, 1885) & & + & & \\
\hline Cercidia prominens (Westring, 1851) & & & & 1 운 \\
\hline Larinioides cornutus (Clerck, 1758) & & + & & \\
\hline Parazygiella dispar (Kulczyński, 1885) & + & & & \\
\hline \multicolumn{5}{|l|}{ Clubionidae } \\
\hline Clubiona furcata Emerton, 1919 & & & & $40^{7} \sigma^{7}$ \\
\hline Clubiona kulczynskii Lessert, 1905 & + & & & \\
\hline Clubiona latericia Kulczyński, 1926 & + & & & \\
\hline \multicolumn{5}{|l|}{ Dictynidae } \\
\hline Arctella lapponica Holm, 1945 & & & $2 \mathrm{j}$ & \\
\hline Hackmania prominula (Tullgren, 1948) & & + & & \\
\hline \multicolumn{5}{|l|}{ Gnaphosidae } \\
\hline Gnaphosa microps Holm, 1939 & & + & & \\
\hline Haplodrassus moderatus (Kulczyński, 1897) & & + & & \\
\hline Haplodrassus soerenseni (Strand, 1900) & & + & & \\
\hline Micaria pulicaria (Sundevall, 1831) & & + & & \\
\hline \multicolumn{5}{|l|}{ Hahniidae } \\
\hline Hahnia ononidum Simon, 1875 & & + & & \\
\hline \multicolumn{5}{|l|}{ Linyphiidae } \\
\hline Agnyphantes expunctus (O.P-Cambridge, 1875) & & + & & \\
\hline Ayneta amersaxatilis Saaristo et Koponen, 1998 & & & & $20^{2}+$ \\
\hline Agyneta mollis (O.P.-Cambridge, 1871) & + & & & \\
\hline Agyneta olivacea (Emerton, 1882) & & & & 19 \\
\hline Agyneta pseudosaxatilis Tanasevitch, 1984 & & & 19 & \\
\hline Allomengea scopigera (Grube, 1859$)$ & + & & & \\
\hline Anguliphantes dybowskii (O. P.-Cambridge, 1873) & & & & 4 4우 \\
\hline Anguliphantes karpinskii (O.P.-Cambridge, 1873) & + & & & \\
\hline Aphileta misera (O.P.-Cambridge, 1882) & + & & & \\
\hline Asperthorax borealis Ono et Saito, 2001 & + & & & \\
\hline Bathyphantes eumenis (L.Koch, 1879) & + & + & $10^{x}$ & $40+9$ \\
\hline Bathyphantes gracilis (Blackwall, 1841) & + & & & \\
\hline Bathyphantes humilis (L.Koch, 1879) & & + & & \\
\hline Bathyphantes pogonias Kulczyński, 1885 & + & + & & 290 \\
\hline Bathyphantes setiger F.O. P.-Cambridge, 1894 & & & & $40^{7} 0^{7} 3$ 우 \\
\hline Centromerus sylvaticus (Blackwall, 1841) & + & & & \\
\hline
\end{tabular}


Table 1 (contituing) Таблица 1 (продолжение)

\begin{tabular}{|c|c|c|c|c|}
\hline Ceraticelus bulbosus (Emerton, 1882) & + & & $10^{x}$ & \\
\hline Ceraticelus orientalis Eskov, 1987 & & & & $1+9$ \\
\hline Ceratinella wideri (Thorell, 1871) & & & & $10^{x}$ \\
\hline Cnephalocotes obscurus (Blackwall, 1834) & & & & $1+9$ \\
\hline Concavocephalus rubens Eskov, 1989 & & & & $10^{\top} 10$ 우 \\
\hline Dactylopisthes video (Chamberlin et Ivie, 1947) & & + & & \\
\hline Dicymbium libidinosum (Kulczyński, 1926) & + & + & & 3 우우 \\
\hline Diplocentria bidentata (Emerton, 1882) & + & + & $30^{\top} \sigma^{\top} 6+9$ & $30^{\top} 0^{\top} 21$ 우 \\
\hline Dismodicus bifrons (Blackwall, 1841) & & + & & $9+0$ \\
\hline Erigone atra Blackwall, 1833 & + & & & $10^{7}$ \\
\hline Erigone cristatopalpus Simon, 1884 & & + & & \\
\hline Estrandia grandaeva (Keyserling, 1886) & + & + & & \\
\hline Flagelliphantes flagellifer (Tanasevitch, 1987) & + & & & \\
\hline Gnathonarium taczanowskii (O.P.-Cambridge, 1873) & + & & & 19 \\
\hline Gonatium rubens (Blackwall, 1833) & & & & 1 우 \\
\hline Halorates holmgreni (Thorell, 1872) & & & & $10^{\top} 6$ 우 \\
\hline Hilaira canaliculata (Emerton, 1915) & + & & $10^{T}$ & 4 우우 \\
\hline Hilaira devitata Eskov, 1987 & + & & & \\
\hline Hilaira herniosa (Thorell, 1875) & + & + & 200 & 200 \\
\hline Hilaira minuta Eskov, 1979 & & & 19 & $2+9$ \\
\hline Hilaira pervicax Hull, 1908 & & & 290 & $12+0$ \\
\hline Hilaira sibirica Eskov, 1987 & + & & $4{ }_{+} 4$ & 20 우우 \\
\hline Horcotes strandi (Sytshevskaja, 1935) & & + & & $4 \sigma^{\top} \sigma^{\top} 19$ \\
\hline Hybauchenidium gibbosum (Sorensen, 1898) & + & + & & $10^{\top} 390$ \\
\hline Hylyphantes graminicola (Sundevall, 1830) & + & & & \\
\hline Hypselistes semiflavus (L.Koch, 1879) & + & & & \\
\hline Improphantes complicatus (Emerton, 1882) & + & & 2 우 & $15+9$ \\
\hline Islandiana cristata Eskov, 1987 & & & & $10^{\top} 5$ 우 \\
\hline Kaestneria anceps (Kulczyński, 1885) & + & + & 19 & $70^{\top} 0^{\top} 17+90$ \\
\hline Lepthyphantes luteipes (L.Koch, 1879) & & + & & \\
\hline Lophomma vaccinii (Emerton, 1926) & + & & & \\
\hline Macrargus multesimus (O.P.-Cambridge, 1875) & & + & & \\
\hline Maro sibiricus Eskov, 1980 & & & 1 우 & \\
\hline Maso sundevalli (Westring, 1851) & + & & & $4 \bigcirc^{7} \bigcirc^{7} 8$ + \\
\hline Mecynargus sphagnicola Eskov, 1988 & & & $10^{7}$ & \\
\hline Micrargus herbigradus (Blackwall, 1854) & + & & & \\
\hline Microlinyphia pusilla (Sundevall, 1830) & + & + & & \\
\hline Minyrioloides affinis Schenkel, 1930 & + & + & & \\
\hline Mughiphantes taczanowskii (O.P.-Cambridge, 1873) & + & & 19 & \\
\hline Neriene subarctica Marusik, 1991 ? & & & 1 우 & $1+1 \mathrm{j}$ \\
\hline Obscuriphantes pseudoobscurus Marusik et al., 1996 & & & $10^{7}$ & \\
\hline Oedothorax trilobatus (Banks, 1896) & + & & & \\
\hline Oreoneta magaputo Saaristo et Marusik, 2004 & & + & 290 & $20^{7} \sigma^{\top} 1990$ \\
\hline Oreonetides kolymensis Eskov, 1991 & & & $1+1\left(\bigcirc^{7}\right)$ & \\
\hline Oreonetides vaginatus (Thorell, 1872) & + & + & & $10^{\top} 4$ 우 \\
\hline Oryphantes bipilis (Kulczyński, 1885) & + & + & 1 운 & 3 우우 \\
\hline Paratmeticus bipunctis (Bösenberg et Strand, 1906) & + & & & \\
\hline Parawubanoides unicornis (O.P.-Cambridge, 1873) & & & & $10^{\top} 290$ \\
\hline
\end{tabular}




\begin{tabular}{|c|c|c|c|c|}
\hline Pelecopsis dorniana Heimer, 1987 & & & & $30^{7} 0^{7} 3 \circ 0$ \\
\hline Pelecopsis mengei (Simon, 1884) & & + & & $10^{7} 390$ \\
\hline Pelecopsis parallela $($ Wider, 1834$)$ & + & & & \\
\hline Perregrinus deformis (Tanasevitch, 1982) & + & & $20^{3}+$ & $10^{\Upsilon} 10$ 우 \\
\hline Phlattothrata parva (Kulczyński, 1926) & + & + & 2 2우 & $4 \sigma^{7} O^{7} 4$ + \\
\hline Poeciloneta variegata (Blackwall, 1841) & & & $1 \mathrm{j}$ & \\
\hline Porrhomma montanum Jackson, 1913 & + & + & & \\
\hline Praestigia kulczynskii Eskov, 1979 & + & + & $? 2$ 웅 & 1 우 \\
\hline Pseudocyba miracula Tanasevitch, 1984 & & & & 290 \\
\hline Savignia birostra (Chamberlin et Ivie, 1947) & & + & & $10^{\top} 7$ 우우 \\
\hline Sciastes dubius (Hackman, 1954) & + & & & 400 \\
\hline Scotynotylus cf. millidgei Eskov, 1989 & & & & 1 우 \\
\hline Semljicola beringianus (Eskov, 1989) & & & & 5 우 \\
\hline Semljicola convexus (Holm, 1963) & & & & $3 \sigma^{7} \sigma^{\top} 19+9$ \\
\hline Semljicola lapponicus (Holm, 1939) & + & & & 19 \\
\hline Stemonyphantes sibiricus (Grube, 1861) & + & + & & $1 \mathrm{j}$ \\
\hline Styloctetor lehtineni Marusik et Tanasevitch, 1998 & & + & & 1 우 \\
\hline Tenuiphantes alacris (Blackwall, 1853) & + & & & \\
\hline Tenuiphantes mengei (Kulczyński, 1887) & + & + & & \\
\hline Tenuiphantes nigriventris (L.Koch, 1879) & + & & & \\
\hline Thaleria alnetorum Eskov et Marusik, 1992 & & & & $2 \sigma^{\top} 0^{\top} 19$ \\
\hline Thaleriia sukatchevae Eskov et Marusik, 1992 & & & & $10^{7} 26+9$ \\
\hline Theonina aterrima Eskov et Marusik, 1991 & & & & 19 \\
\hline Tibioploides pacificus Eskov et Marusik, 1991 & + & & & \\
\hline Tibioplus diversus (L.Koch, 1879) & + & & & \\
\hline Tmeticus tolli Kulczyński, 1908 & & + & & $20^{7}+$ \\
\hline Tunagyna debilis (Banks, 1892) & + & & & 290 \\
\hline Walckenaeria cuspidata Blackwall, 1833 & + & + & 1 우 & 9 9o \\
\hline Walckenaeria karpinskii (O.P.-Cambridge, 1873) & + & + & 1 우 & \\
\hline Walckenaeria kochi (O.P.-Cambridge, 1872) & + & & & \\
\hline Walckenaeria korobeinikovi Esyunin et Efimik, 1996 & + & & & 6 우우 \\
\hline Walckenaeria nudipalpis (Westring, 1851) & + & & & \\
\hline Walckenaerianus aimakensis Wunderlich, 1995 & + & & & \\
\hline Wubanoides fissus (Kulczyński, 1926) & & + & & 290 \\
\hline Zornella orientalis Marusik, Koponen et Buckle, 2007 & & & 1 우 & \\
\hline \multicolumn{5}{|l|}{ Liocranidae } \\
\hline Agroeca ornata Banks, 1892 & + & & & \\
\hline \multicolumn{5}{|l|}{ Lycosidae } \\
\hline Alopecosa aculeata (Clerck, 1758) & & + & & \\
\hline Pardosa atrata (Thorell, 1873) & & + & & \\
\hline Pardosa palustris (Linnaeus, 1758) & & + & $1 \mathrm{j}$ & $2 \mathrm{j}$ \\
\hline Pardosa cf. prosaica Chamberlin et Ivie, 1947 & & + & & \\
\hline Pardosa riparia (C.L. Koch, 1847) & + & & & \\
\hline Pardosa tesquorum (Odenwall, 1901) & + & & & \\
\hline Piratula canadensis (Dondale et Redner, 1981) & + & & & \\
\hline Tricca alpigena (Doleschall, 1852) & & & & 290 \\
\hline
\end{tabular}


Table 1 (contituing) Таблица 1 (продолжение)

\begin{tabular}{|c|c|c|c|c|}
\hline Philodromidae & & & & \\
\hline Tibellus maritimus (Menge, 1875) & + & + & $10^{2}$ & $20^{7} \sigma^{\pi}$ \\
\hline \multicolumn{5}{|l|}{ Salticidae } \\
\hline Heliophanus camtschadalicus Kulczyński, 1885 & + & & & 1 우 \\
\hline Sitticus caricis (Westring, 1861) & + & & & \\
\hline Sitticus cutleri Prószyński, 1980 & & & & 19 \\
\hline Sitticus floricola (C.L. Koch, 1837) & & + & & $10^{x}$ \\
\hline \multicolumn{5}{|l|}{ Tetragnathidae } \\
\hline Pachygnatha clercki Sundevall, 1823 & + & & & \\
\hline Tetragnatha dearmata Thorell, 1873 & & & & $1 \mathrm{j}$ \\
\hline Tetragnatha extensa (Linnaeus, 1758) & + & + & & $3 \mathrm{j}$ \\
\hline \multicolumn{5}{|l|}{ Theridiidae } \\
\hline Canalidion montanum (Emerton, 1882) & + & & & \\
\hline Enoplognatha caricis (Fickert, 1876) & + & & & $1 \mathrm{j}$ \\
\hline Robertus lividus (Blackwall, 1836) & + & & & \\
\hline Robertus lyrifer Holm, 1939 & + & & $? 19$ & $30^{\top} 0^{7} 8$ 8 +9 \\
\hline Robertus ungulatus Vogelsanger, 1944 & + & & & \\
\hline Rugathodes aurantius (Emerton, 1915) & + & & & \\
\hline Thymoites bellissimus (L. Koch, 1879) & + & & & \\
\hline \multicolumn{5}{|l|}{ Thomisidae } \\
\hline Ozyptila gertschi Kurata, 1944 & + & & & \\
\hline Ozyptila orientalis Kulczyński, 1926 & & & & $20^{\top} 0^{\top} 7+0$ \\
\hline Ozyptila trux (Blackwall, 1846) & & + & $1+2 \mathrm{j}$ & $1+3 \mathrm{j}$ \\
\hline Xysticus albidus Grese, 1909 & & & & $1 \mathrm{j}$ \\
\hline Xysticus britcheri Gertsch, 1934 & + & + & $10^{x}$ & $10^{T}$ \\
\hline \multicolumn{5}{|l|}{ Zoridae } \\
\hline Zora cf. nemoralis (Blackwall, 1861) & $\mathrm{f}$ & & & $10^{7}$ \\
\hline \multicolumn{5}{|l|}{ OPILIONES, Phalangiidae } \\
\hline Mitopus morio (Fabricius, 1779) & + & + & $3 \mathrm{j}$ & $7 \mathrm{j}$ \\
\hline
\end{tabular}

2002 [cf. Platnick, 2013], a species known from Taimyr to eastern Yakutia. Specimens from Koryakia correspond well with figures provided for $A$. amersaxatilis, but not to those of $A$. yakutsaxatilis. If it is agreed that two names are synonyms, then our record is first for Kamchatka and the easternmost record of the species in Palaearctic. If it is considered that the two names represent two separate species (as we do), then the record from Achayvayam Village is first for the whole Palaearctic and westernmost in the range.

Agyneta olivacea (Emerton, 1882)*

COMMENTS. The species is widespread in the Holarctic [Platnick, 2013], but was never reported from Kamchatka.

Agyneta pseudosaxatilis Tanasevitch, 1984^

COMMENTS. The species has a Siberian range, and was previously reported from southern Kamchatka [Eskov, 1994].
Anguliphantes dybowskii (O. Pickard-Cambridge, $1873)^{* \mathrm{E}}$

Figs 6-12.

COMMENTS. The species has a Siberian range [Eskov, 1994], but it was never reported from the Kamchatka Peninsula. The present record is easternmost in the whole range. Here we provide figures of the copulatory organs of this species because they were not properly illustrated before.

Bathyphantes setiger F.O. Pickard-Cambridge, 1894*

COMMENTS. Although the species has a transPalaearctic range [Platnick, 2013], and is known from Chukotka [Marusik et al., 1992], it was never reported from Kamchatka before.

Ceraticelus orientalis Eskov, 1987^

COMMENTS. The species is known from northeastern Asia only [Eskov, 1994]. The record from Achayvayam is the most northeastern of the range. 


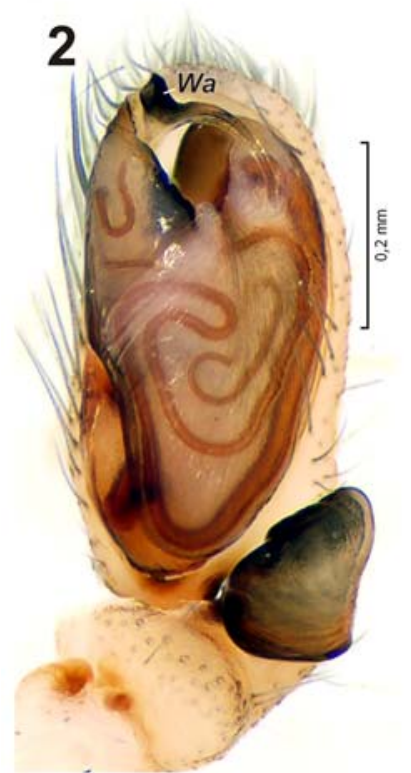

\section{3}

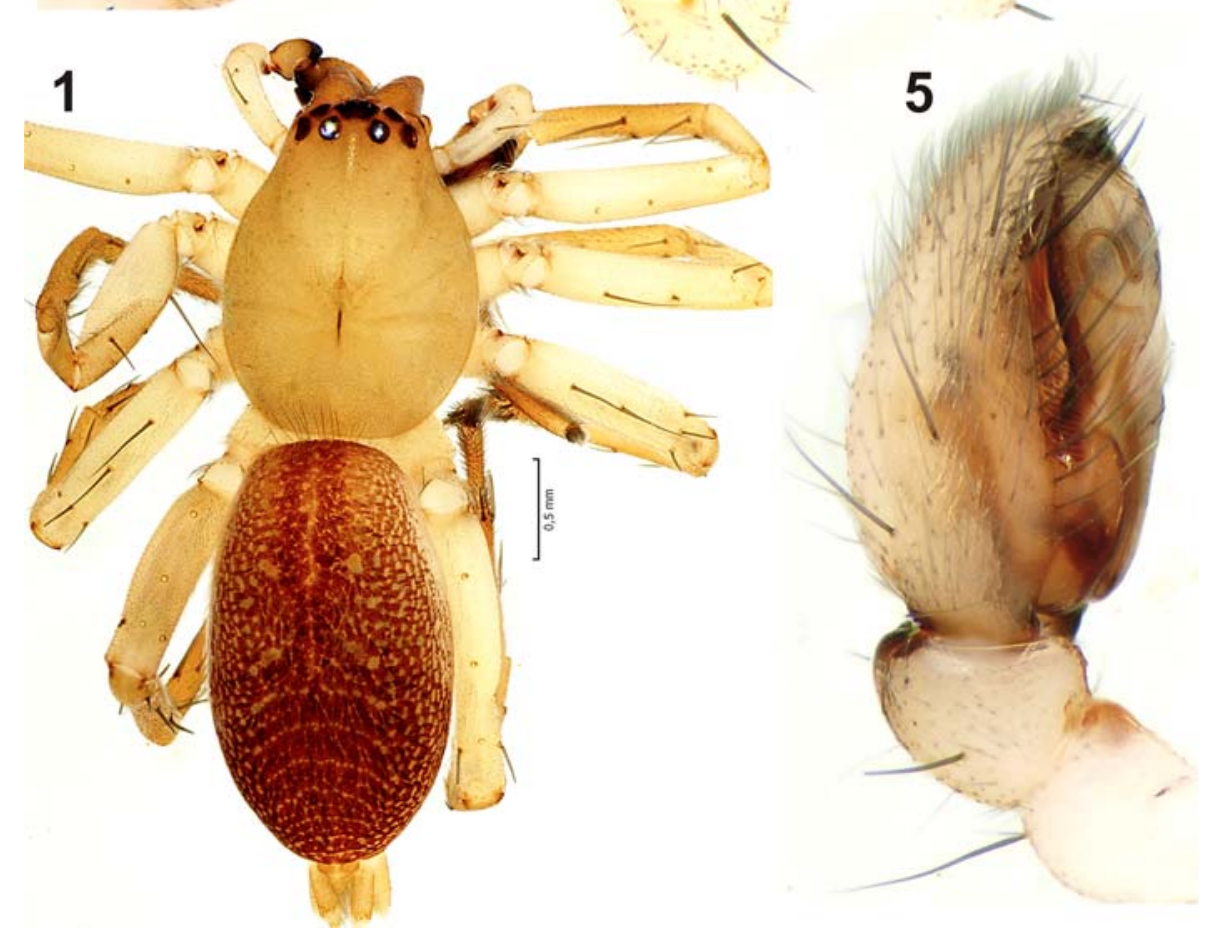

Figs 1-5. Habitus (1) and palp (2-5) of Clubiona furcata male. 1, 3- dorsal; 2 - ventral; 4 - retrolateral; 5 - prolateral. Abbreviation: $\mathrm{Wa}$ - "wart".

Рис. 1-5. Габитус (1) и пальпа (2-5) самца Clubiona furcata. 1, 3 - сверху; 2 - снизу; 4 - ретролатерально; 5 пролатерально.

Сокращение: $W a$ - “бородавка".

Ceratinella wideri (Thorell, 1871)*E

COMMENTS. Although the species is known from Fennoscandia to Magadan Area, it was never found in Kamchatka [Mikhailov, 1997]. Present record is the most eastern of the range.
Cnephalocotes obscurus (Blackwall, 1834) ${ }^{\wedge \mathrm{E}}$

COMMENTS. The species has a trans-Palaearctic range [Platnick, 2013]. The record from Koryakia is the most eastern of the range. 


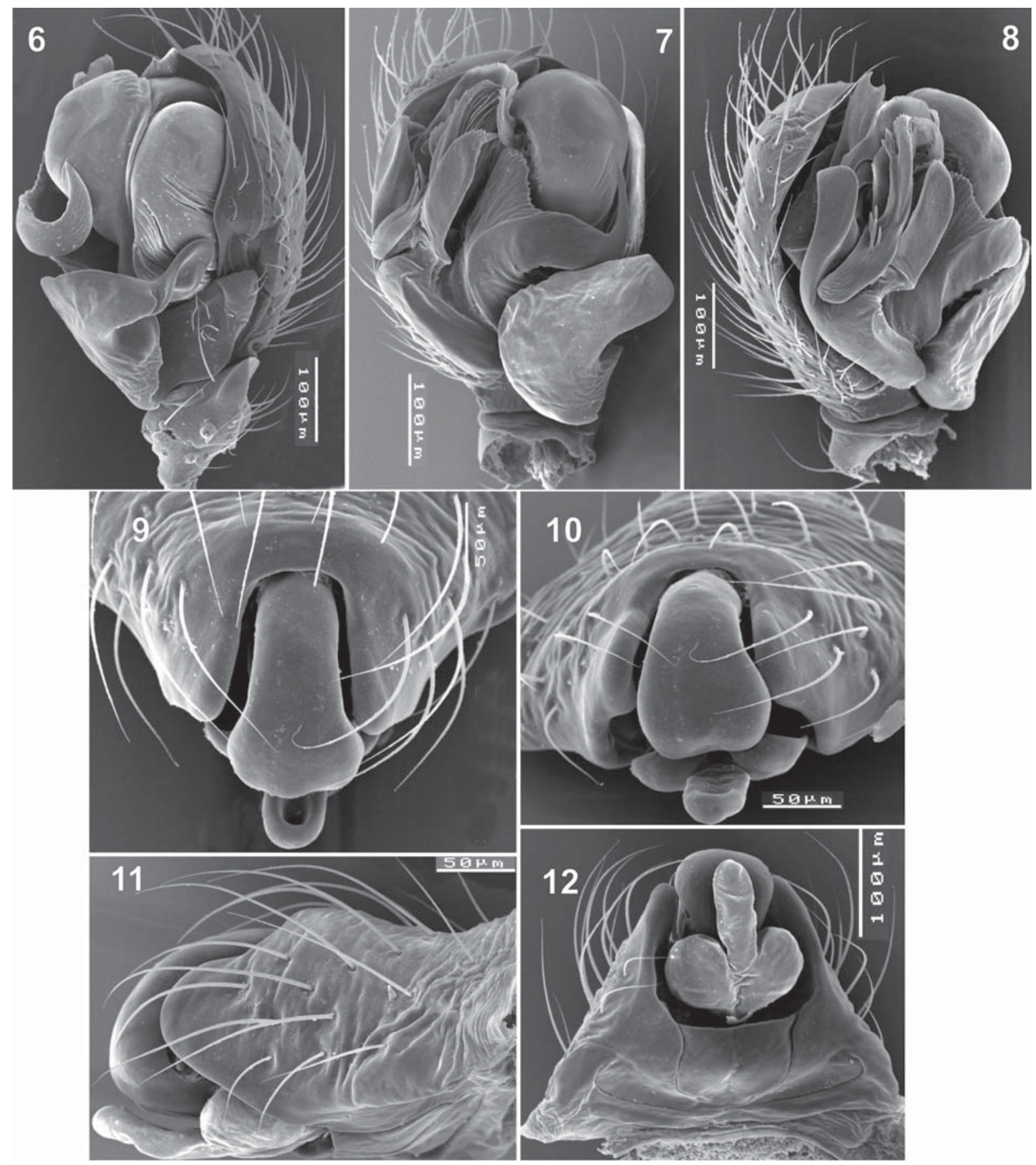

Figs 6-12. Male palp (6-8) and epigyne (9-12) of Anguliphantes dybowskii from environs of Magadan. 6 - retrolateral; 7, 9 ventral; 8 - prolateral; 10 - caudal; 11 - lateral, 12 - dorsal.

Рис. 6-12. Пальпа самца (6-8) и эпигина (9-12) Anguliphantes dybowskii из окрестностей Магадана. 6 - ретролатерально; 7,9- снизу; 8 - пролатерально; 10 - сзади; 11 - латерально, 12 - сверху.

Concavocephalus rubens Eskov, 1989*E

COMMENTS. The species was known from Yenisei to Kolyma River [Eskov, 1994]. The current record is the most eastern of the species and the genus.
Dismodicus bifrons (Blackwall, 1841)

Figs 13-16.

COMMENTS. This species was already reported from the Karaganski Island [Marusik \& Khrulyova, 

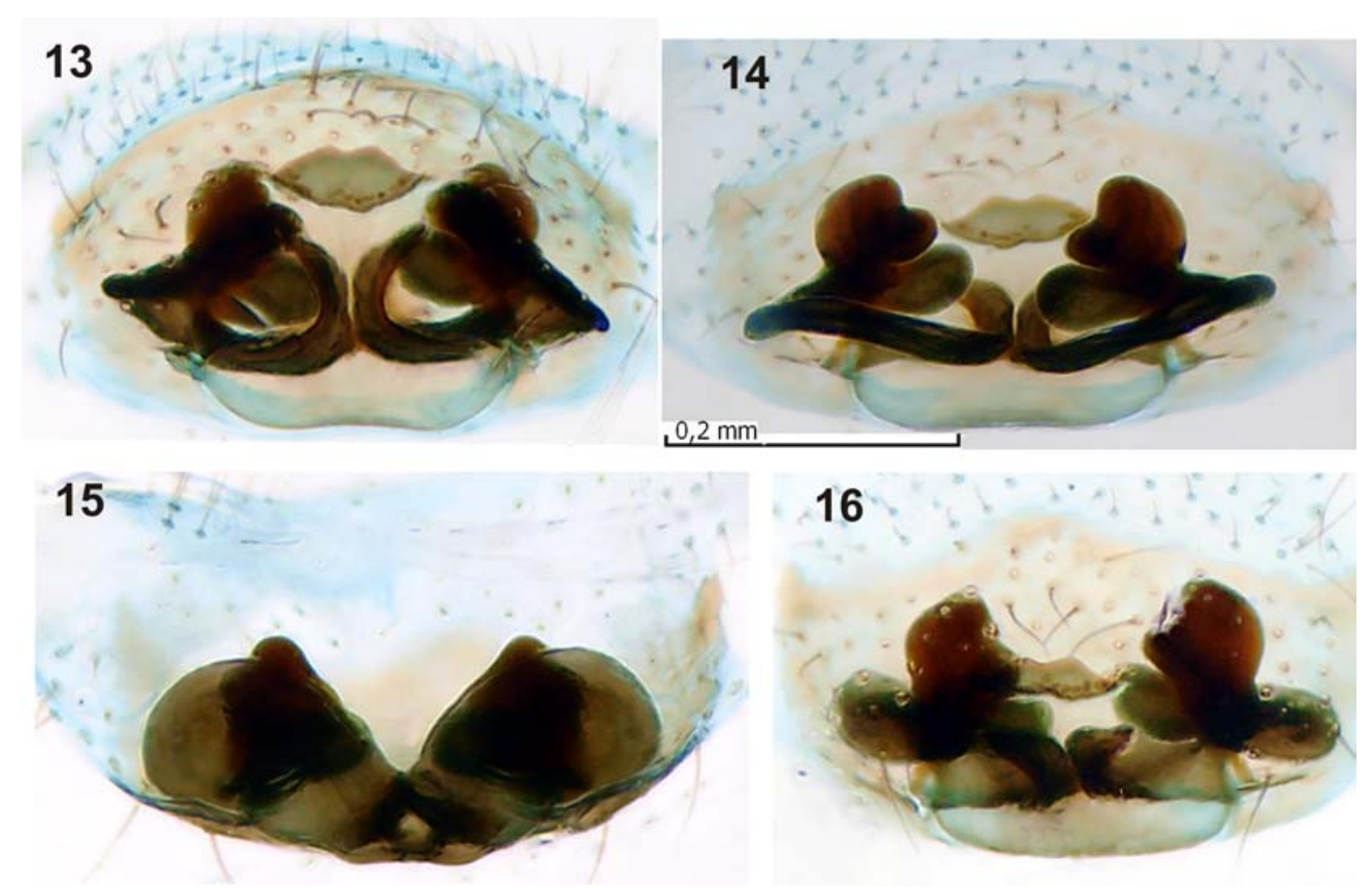

Figs 13-16. Epigyne of Dismodicus bifrons (after maceration). 13 - ventral; 14 - dorsal; 15 - caudal; 16 - anterio-ventral. Рис. 13-16. Эпигина Dismodicus bifrons (после мацерации). 13 - снизу; 14 - сверху; 15 - сзади; 16 - спереди-снизу.

2011], on the basis of a singleton female, as D. alticeps Chamberlin \& Ivie, 1947. Comparison of the vulva of this specimen, and of specimens from Achayvayam Village with specimens from Finland, reveals no differences. Because vulva of this species was not properly illustrated before, here we provide figures of macerated epigyne and show the unusual basal plates.

Gonatium rubens (Blackwall, 1833)*

COMMENTS. The species is known across whole Palaearctic [Platnick, 2013], but it was never reported from Kamchatka.

Halorates holmgreni (Thorell, 1872) ${ }^{\wedge}$

COMMENTS. The species has a Holarctic range [Platnick, 2013], and most of its localities lie in the tundra zone [Marusik \& Eskov, 2009].

Hilaira minuta Eskov, 1979*

COMMENTS. The species is known from Yenisei River to Anadyr' River mouth [Eskov, 1994]. It was never reported from Kamchatka before.

Hilaira pervicax Hull, 1908*E

COMMENTS. Earlier this species was known from Europe to Kolyma River [Mikhailov, 1997]. The record from Koryakia is the most eastern of the range.

Islandiana cristata Eskov, 1987^

COMMENTS. The species is distributed across Siberia, and also known from Alaska and the Yukon Territory in Canada [Eskov, 1994; Platnick, 2013].
Maro sibiricus Eskov, 1980^E

COMMENTS. The species is known in Siberia east of Yenisei to Kamchatka [Mikhailov, 1997]. The record from Koryakia is the most eastern in the range.

Mecynargus sphagnicola (Holm, 1939)*

COMMENTS. Although the species is known from the Palaearctic and Greenland [Platnick, 2013], it was never found in Kamchatka before.

\section{Neriene cf. subarctica Marusik, 1991*}

Figs 17-20.

COMMENTS. Neriene subarctica is known by the original description only. It was found from eastern Yakutia and south part of Magadan Area. Although fovea of epigyne of Kamchatkan specimens are similar to specimens from Magadan Area, they lack plate covering fovea and have different spination. Most likely it is an undescribed species, but we refrain from its description until males are found.

Obscuriphantes pseudoobscurus Marusik, Hippa et Koponen, 1996^

COMMENTS. The species known across whole Siberia [Marusik et al., 2000].

Oreonetides kolymensis Eskov, 1991*

COMMENTS. This species was known from northern Cisamuria to Chaun Bay in Chukotka [Eskov, 1994]. 


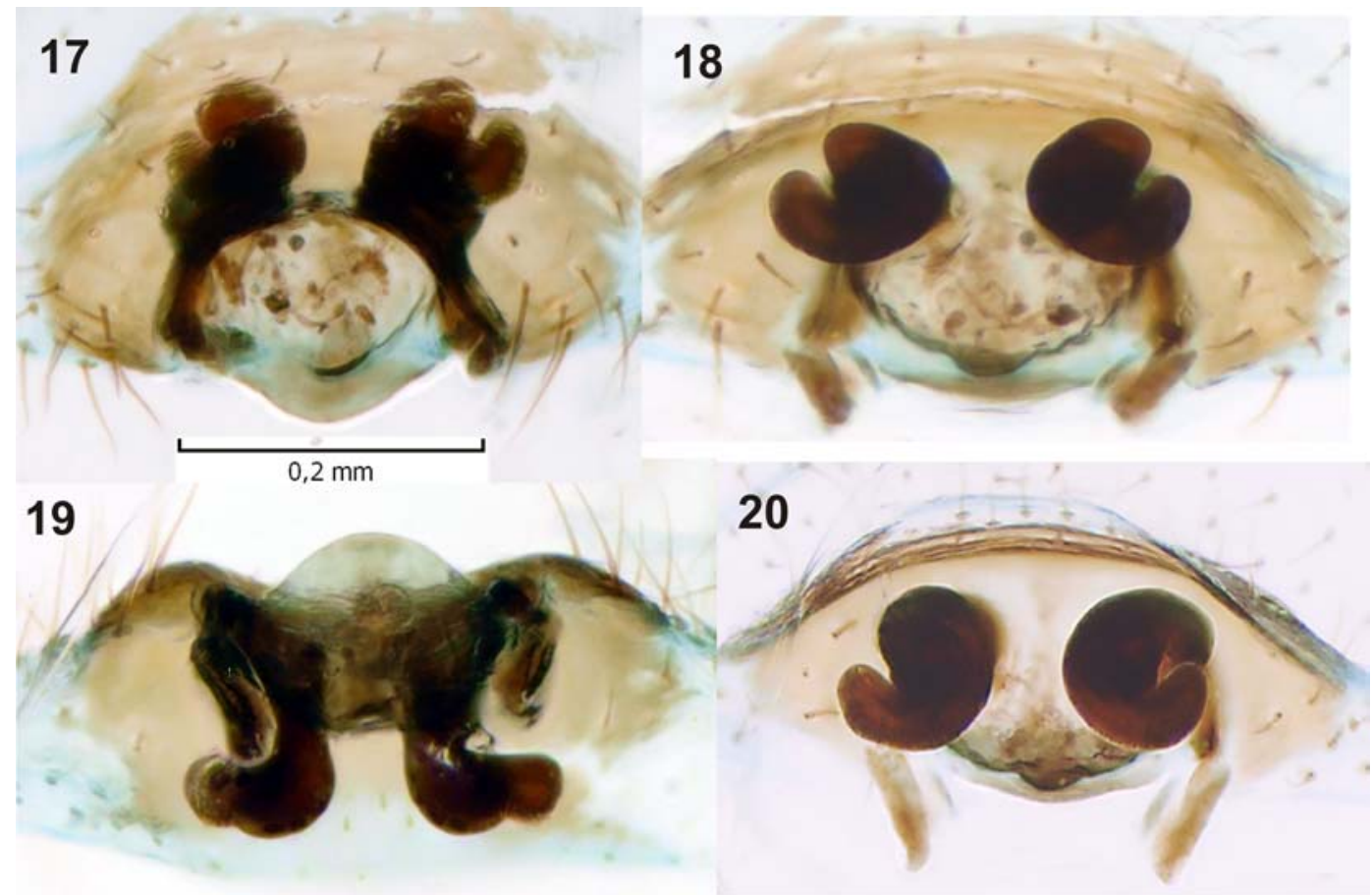

Figs 17-20. Epigyne of Neriene subarctica ? (after maceration). 17 - ventral; 18 - anterio-dorsal; 19 - caudal; 20 - anterior. Рис. 17-20. Эпигина Neriene subarctica ? (после мацерации). 17 - снизу; 18 - спереди-сверху; 19 - сзади; 20 - спереди.

\section{Parawubanoides unicornis (O. Pickard-Cambridge, $1873)^{\wedge \mathrm{E}}$}

COMMENTS. The species was known from Yenisei River to Kamchatka Peninsula [Eskov, 1994]. The record from Koryakia is the most eastern of the range.

Pelecopsis dorniana Heimer, 1987*

COMMENTS. Although the species has a widespread Siberian range, and is known from Yenisei to eastern Chukotka [Eskov, 1994], it was never reported from Kamchatka.

Poeciloneta variegata (Blackwall, 1841)^

COMMENTS. The species is known from Palaearctic and western Nearctic [Marusik et al., 2000]. It was known previously in south Kamchatka .

Pseudocyba miracula Tanasevitch, 1984*E

COMMENTS. The species and monotypic genus were known from Polar Ural to Kolyma River [Eskov, 1994]. The current record extends the genus and species range about $20^{\circ}$ to the east.

Scotinotylus cf. millidgei Eskov, 1989*

COMMENTS. We can not identify with certainty a single female found in Koryakia. We report this species because it belongs to this genus, which was previously unknown in Koryakia.

Semljicola beringianus (Eskov, 1989)*W

COMMENTS. The species is known in Siberia east of $140^{\circ} \mathrm{E}$ [Saaristo \& Eskov, 1996].

\section{Semljicola convexus (Holm, 1963)*W}

COMMENTS. So far, the species was known from eastern Chukotka and northwestern Nearctic [Saaristo \& Eskov, 1996], and has a trans-Beringian range. The present record is the most southwestern extension of the range.

Thaleria alnetorum Eskov et Marusik, 1992*

COMMENTS. This species is known in northern Asia east of Lena River [Eskov, 1994]. The genus and species were not reported from Kamchatka Peninsula before.

Thaleria sukatchevae Eskov et Marusik, 1992*E

COMMENTS. The species was known from Chita to Magadan Area [Eskov, 1994]. The record from Koryakia is the easternmost of the range.

Theoneta aterrima Eskov et Marusik, 1991*

COMMENTS. The species was known from the Amur Area [Tanasevitch, 2006] to the Upper Kolyma Area [Eskov, 1994]. The record from Koryakia is the most eastern for the species and the genus.

\section{Walckenaeria korobeinikovi Esyunin et Efimik, $1996^{\mathrm{E}}$}

COMMENTS. The species is known from east of Finland to Kamchatka and western Chukotka [Marusik et al., 2000; Tanasevitch, 2006]. The record from Koryakia is the most eastern of the range. 

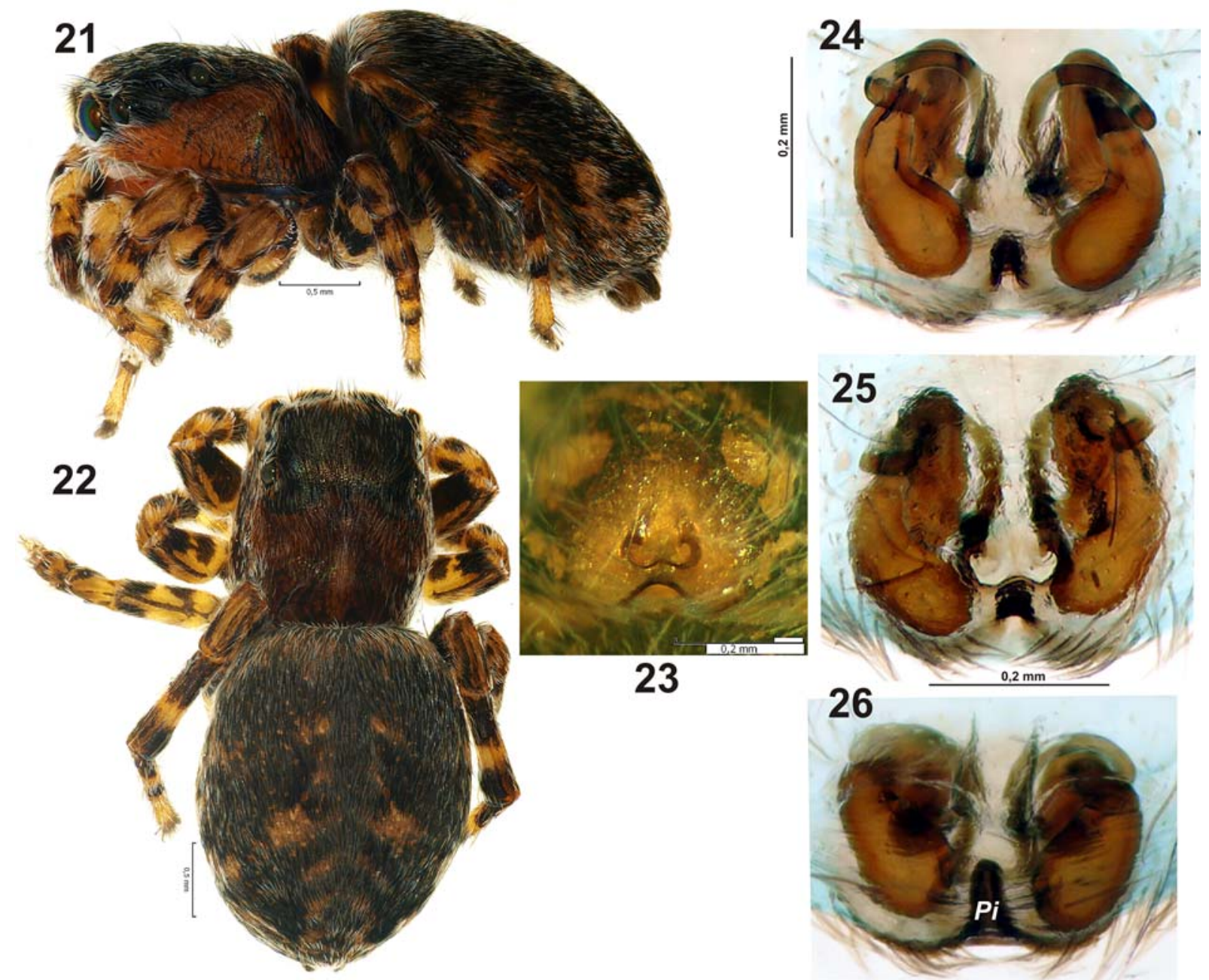

23

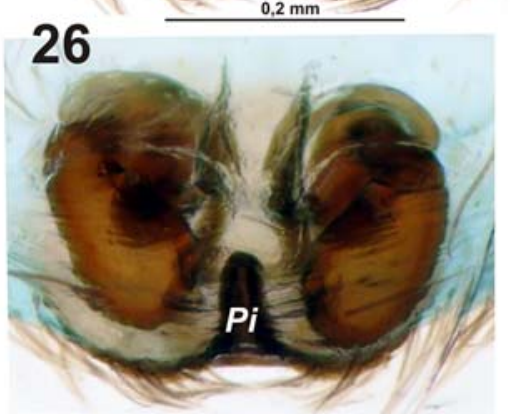

Figs 21-26. Female of Sitticus cutleri. 21-22 - habitus, lateral and dorsal; 23 - intact epigyne, ventral; 24-26 - epigyne after maceration, dorsal, ventral and caudal (showing deep pit, $P i$ ).

Pис. 21-26. Самка Sitticus cutleri. 21-22 - габитус, латерально и сверху; 23 - интактная эпигина, снизу; 24-26 - эпигина после мацерации, сверху, снизу и сзади (показана глубокая ямка, $P i)$.

Zornella orientalis Marusik, Koponen et Buckle, 2007 *

COMMENTS. This species was known from northern Cisokhotia and the upper reaches of the Kolyma River [Marusik et al., 2007] only. The new record extends the known range of the species about $20^{\circ}$ to the East.

Tanasevitch [2008] consider this species as synonym of Z. cultrigera (L. Koch, 1879) known from Fennoscandia to Yakutia and northern Cisamuria.

\section{LYCOSIDAE}

Tricca alpigena (Doleschall, 1852)*

COMMENTS. This species has a circum-Holarctic range [Platnick, 2013], and is widespread in Siberia [Mikhailov, 1997]. Neither the species nor the genus were never reported from Kamchatka Peninsula before.

\section{SALTICIDAE}

Sitticus cutleri Prószyński, 1980*

Figs 21-26.

COMMENTS. This species has Siberio - West Nearctic range. Within Siberia it was known from Yenisei to Kolyma River. The record from Koryakia is the easternmost in the Palaearctic. The single female has epigyne and vulva corresponding well with the figures published in the literature. Females of this species can be easily distinguished from all congeners by having rather deep pit in posterior part of epigyne (Figs 2426). It is worth noting that female was collected almost in the same habitat as male of S. floricola. 


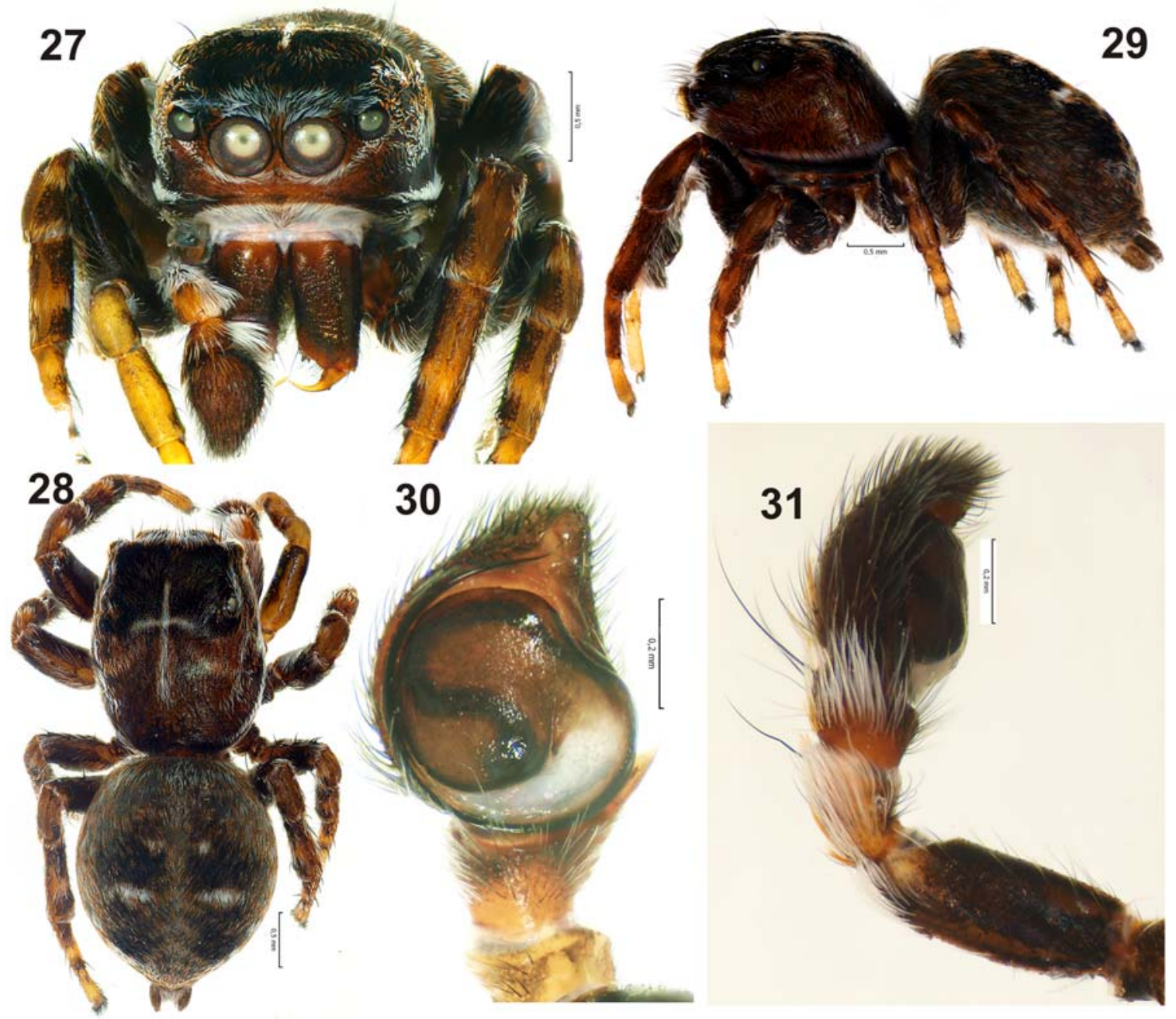

Figs 27-31. Male of Sitticus floricola. 27-29 - habitus, frontal, dorsal and lateral; 30 - palp, ventral; 31 - palp, prolateral (shows characteristic white hairs).

Рис. 27-31. Самец Sitticus floricola. 27-29 — габитус, фронтально, сверху и латерально; 30 - пальпа, снизу; 31 - пальпа, пролатерально (показаны характерные белые волоски).

Sitticus floricola (C.L. Koch, 1837)

Figs 27-31.

COMMENTS. This species was already reported from Koryakia [Marusik \& Khrulyova, 2011]. The present record is the northernmost in Far East Asia. Although this species is well illustrated in many publications [cf. Platnick, 2013], habitus, pattern and diagnostic white hairs on male palp were never properly documented. Therefore, we provide figures of our specimen. It is worth noting that $S$. floricola is a single species in the floricola-group that has no fine loop of the seminal duct in the tegulum (Fig. 30). This fine loop is species specific in the group.

\section{TETRAGNATHIDAE}

Tetragnatha dearmata Thorell, $1873^{\wedge}$

COMMENTS. The species has Holarctic range [Platnick, 2013], and was known in Koryakia before. Although we have only juvenile specimens, it was easy to distinguish it from T. extensa, the only other species of the genus known in northeastern Siberia because of the lack of an sternal pattern.

\section{THERIDIIDAE}

Robertus lyrifer Holm, 1939

Figs 32-43.

COMMENTS. This species was recorded from Koryakia earlier [Marusik et al., 2010]. Here we provide 

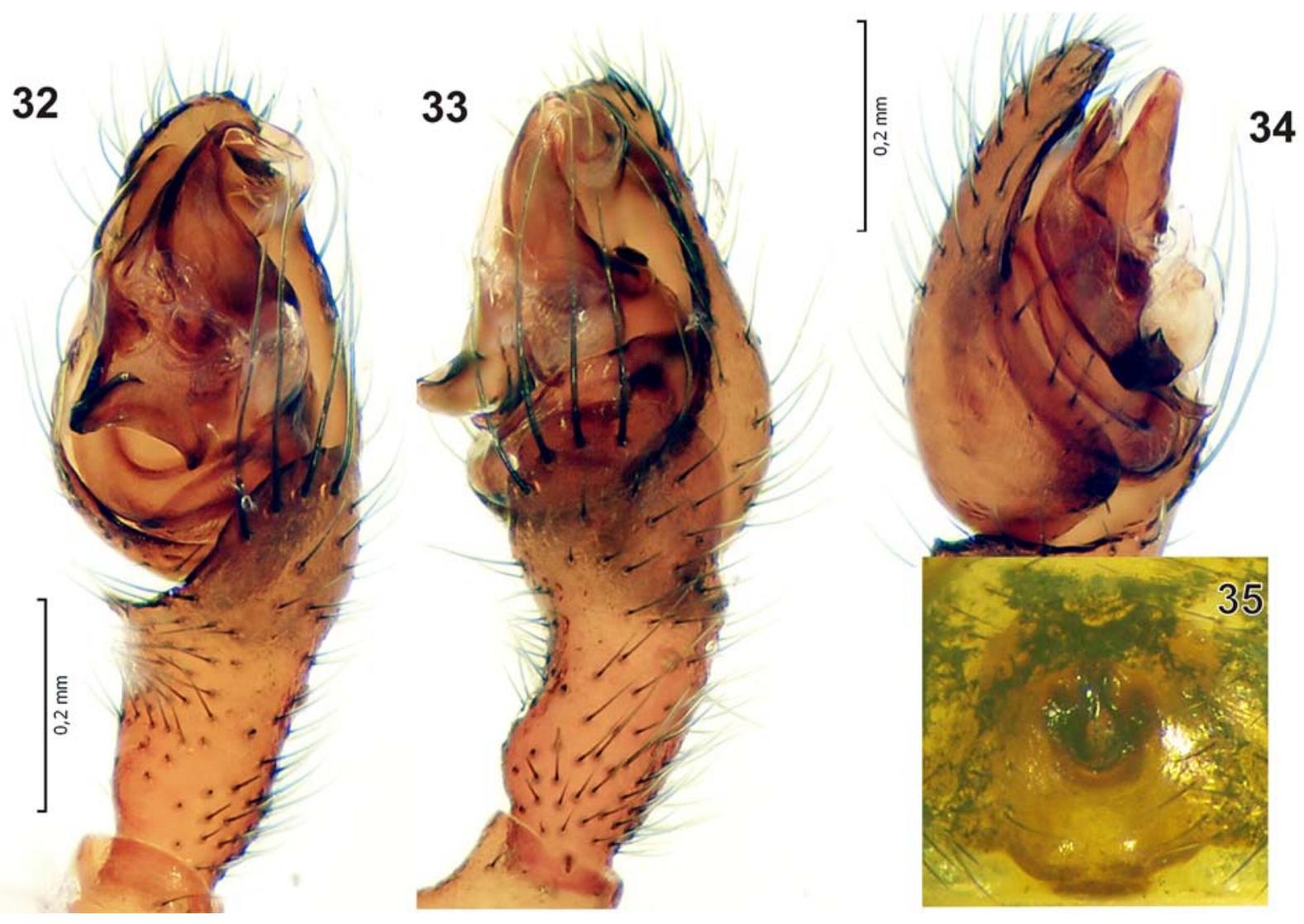

Figs 32-35. Robertus lyrifer. 32-34 - palp, ventral, retrolateral and prolateral; 35 - epigyne, ventral.

Рис. 32-35. Robertus lyrifer. 32-34 - пальпа, снизу, ретролатерально и пролатерально; 35 - эпигина, снизу.

figures of this species because if was never illustrated in details. Male of this species have modified palpal tibia with hairy field. This field besides hairs has pores (Fig. 41).

\section{THOMISIDAE}

Ozyptila orientalis Kulczyński, $1926^{\wedge}$

COMMENTS. This species was described from the southern part of Kamchatka, but was not known from Koryakia.

\section{Xysticus albidus Grese, 1908*}

COMMENTS. This species has trans-Palaearctic range and most of its records lie in tundra zone [Marusik \& Eskov, 2009]. While we have only a subadult male, it was easy to determine the identification thanks to lack of processes in bulbal part, and the large retrolateral extension corresponding to a large coiled embolus.

\section{ZORIDAE}

Zora cf. nemoralis (Blackwall, 1861)

COMMENTS. It is an undescribed species close to Z. nemoralis. It is widespread in Siberia. Earlier it was reported as Zora sp. from western Koryakia [Marusik et al., 2010] on the basis of females, which are indistinguishable from $Z$. nemoralis.

\section{Conclusions}

The new material from Eastern Koryakia brought 37 new species and one family (Agelenidae) records to Koryakia. Of them, 25 species, six genera (Arctella Holm, 1939; Concavocephalus Eskov, 1989; Pseudocyba Tanasevitch, 1984; Thaleria Tanasevitch, 1984; Theoneta Eskov et Marusik, 1991, Tricca Simon, 1889 and Zornella Jackson, 1932) are new for Kamchatka Peninsula. For 11 species, record from eastern Koryakia is easternmost in the range. For three species of Linyphiidae, Koryakia is westernmost locality in the range.

Totaling the numbers found of the newly identified species found in Koryakia (which reached 148) (Table 1), numbers of species found in Kamchatka Peninsula became 264. While numbers of species found in Koryakia and Kamchatka became higher, nevertheless they remain poorly studied in comparison to adjacent Magadan Area, Chukotka or Sakhalin. We expect not less than 500 species in Kamchatka Peninsula and not less than 300 in Koryakia. Most of new finds can be in Linyphiidae, a most diverse family in the North. If not 

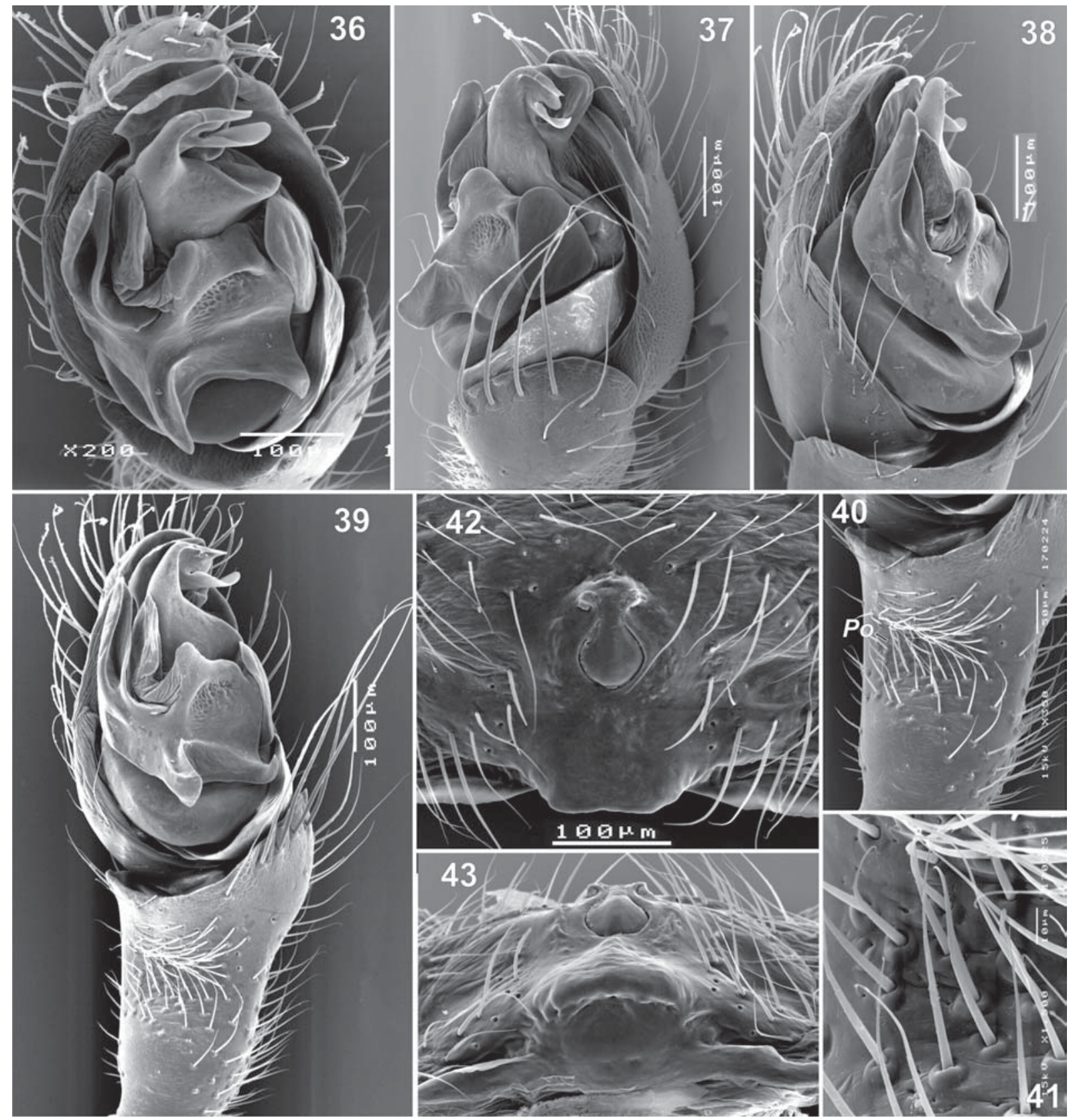

Figs 36-42. Robertus lyrifer (from environs of Magadan). 36-38 - bulbus and cymbium, anterior, retrolateral and prolateral; 39 male palp, ventral; 40 - male palpal tibia; 41 - same, showing hairy area with pores (Po); 42-43 — epigyne, ventral and caudal.

Рис. 36-42. Robertus lyrifer (из окрестностей Магадана). 36-38 - бульбус и цимбиум, спереди, ретролатерально и пролатерально; 39 - пальпа самца, снизу; 40 - голень пальпы самца; 41 - то же самое, показана зона с порами (Ро); 42-43 — эпигина, снизу и сзади.

speaking in absolute numbers, but in relative, many new finds will be in Lycosidae and Gnaphosidae and in other groups of wandering spiders. Pitfall traps, most effective method for collecting wandering spiders, was never applied on the peninsula, but only on Karaginski Island [Marusik \& Khrulyova, 2011].

ACKNOWLEDGEMENTS. We thank Mykola M. Kovblyuk (Simferopol, Ukraine) and Sergei L. Esyunin
(Perm, Russia) for reviewing this manuscript. English of the final draft was kindly checked by Robin Leech (Edmonton, Canada). This work was supported in part by the Russian Foundation for Basic Research (grants \#\# 11-0401716 and 12-04-01548) as well as by the Presidium of the Far Eastern Branch of the Russian Academy of Sciences (\# 12-III-Д-06021 and 13-III-Д-06-003). 


\section{References}

Eskov K.Yu. 1994. Catalogue of the linyphiid spiders of northern Asia (Arachnida, Araneae, Linyphiidae). Sofia: Pensoft Publishers. $144 \mathrm{pp}$.

Marusik Yu.M., Buckle D.J., Koponen S. 2007. A survey of the Holarctic Linyphiidae (Aranei), a review of the erigonine genus Zornella Jackson, 1932 // Acta Zootaxonomica Sinica. Vol.32. No.1. P.21-34.

Marusik Yu.M., Eskov K.Yu. 2009. Spiders (Arachnida: Aranei) of the tundra zone of Russia // S.I. Golovatch et al. (eds.). Species and Communities in Extreme Environments. Festschrift towards the 75th Anniversary and a Laudatio in Honour of Academician Yuri Ivanovich Chernov. Sofia-Moscow: Pensoft Publishers \& KMK Scientific Press. P.131-164.

Marusik Yu.M., Eskov K.Yu., Kim J.P. 1992 A check-list of spiders (Aranei) of Northeast Asia // Korean Arachnol. Vol.8. No.1-2. P.129-158.

Marusik Yu.M., Khrulyova O.A. 2011 First data on spiders and harvestmen (Arachnida: Aranei, Opiliones) from Karaginski Island, Eastern Koryakia, Kamchatka Peninsula // Arthropoda Selecta. Vol.20. No.4. P.323-329.

Marusik Yu.M., Koponen S. 2010. A review of the Holarctic genus Tmeticus Menge, 1868 (Araneae, Linyphiidae), with a description of a new genus // ZooKeys. No.59. P.15-37.

Marusik Yu.M., Logunov D.V., Koponen S. 2000. Spiders of Tuva, South Siberia. Magadan: IBPN FEB RAS. 252 pp.

Marusik Yu.M., Ryabukhin A.S., Kuzminykh G.V. 2010. New data on spiders and harvestmen (Arachnida: Aranei \& Opil- iones) from Western Koryakia, Kamchatka Peninsula // Arthropoda Selecta.Vol.19. No.4. P. 227-236.

Mikhailov K.G. 1997. Catalogue of the spiders of the territories of the former Soviet Union (Arachnida, Aranei). Moscow: Zoological Museum of the Moscow State University. 416 pp.

Mikhailov K.G. 2013. Advances in the study of the spider (Aranei) fauna of Russia and adjacent regions: a 2011 update // Arthropoda Selecta.Vol. 22. No.1. P.47-53.

Mikhailov K.G., Marusik Yu.M. 1991(1995). Spiders of the northeast USSR. Families Clubionidae, Zoridae, Liocraniidae and Gnaphosidae (genus Micaria) (Arachnida, Aranei) // Entomologicheskiye issledovaniya na Severo-Vostoke SSSR. Vladivostok. Vol.2. P.90-113 [in Russian].

Omelko M.M. Marusik Yu.M., Koponen S. 2011. A survey of the East Palaearctic Lycosidae (Aranei). 8. The genera Pirata Sundevall, 1833 and Piratula Roewer, 1960 in the Russian Far East // Arthropoda Selecta. Vol.20. No.3. P.195-232.

Platnick N.I. 2013. The World Spider Catalog, Version 14.0 American Museum of Natural History, online at: http://research.amnh. org/entomology/spiders/catalog/index.html

Saaristo M.I., Eskov K.Yu. 1996. Taxonomy and zoogeography of the hypoarctic erigonine spider genus Semljicola (Araneida, Linyphiidae) // Acta Zool. Fennica. Vol.201. P.47-69.

Tanasevitch A.V. 2006. Five new Linyphiidae spiders from the Russian Far East, with notes on synonymy (Arachnida: Aranei) // Arthropoda Selecta. Vol.15. No.2. P.29-38.

Tanasevitch A.V. 2008. New records of linyphiid spiders from Russia, with taxonomic and nomenclatural notes (Aranei: Linyphiidae) // Arthropoda Selecta. Vol.16. No.2. P.115-135.

Responsible editor S. Koponen 